In summary, third-party practice, when compared with the declaratory action as an approach to the insurer's problem, presents this advantage: it enables the insurer to litigate issues of fact going to coverage without requiring the insurer to absent itself from the action between the assured and injured parties. Compared with the non-waiver agreement, it is clear that third-party practice, in enabling the insurer to present defenses on behalf of the assured as well as to urge its own non-liability under the policy, eliminates both the possibility of rejection of counsel by the assured and the necessity of a second suit to determine the insurer's liability under the policy. Finally, third-party practice moots all question of estoppel. Presumption of jury prejudice, however, and the recognition heretofore accorded the "no-action" clause, are obstacles, to a wider use of the third-party solution. ${ }^{43}$

\title{
COMPETITION AND TV PROGRAM CONTENT
}

"One of the more important sources of the retardation or regression of civilization is man's tendency to use new inventions indiscriminately or too hurriedly without adequate reflection of long-range consequences."

Frankfurter, J., dubitante.*

\section{I}

However anomalous, one of the most significant facts in the on-rush of video has been the absence of a systematic legislative attempt to cope with its problems. Because of the more or less chance presence of a clause in the Communications Act giving the Commission jurisdiction over the transmission of images ${ }^{\mathrm{x}}$ and because the organizations concerned with both the programming and technical phases of TV have to a very large extent been those which have dominated radio, lethargy has thus far won out, and TV has been permitted to trip and stumble along the road originally charted out for its older brother. ${ }^{2}$

The wisdom of such a course is dubious. The decisions of the Commission in

43 Jacobs v. Pellegrino, 154 Misc. 651, 277 N.Y. Supp. 654 (S. Ct., 1935).

* Radio Corp. of America v. United States, 34I U.S. 4I2, 425 (I95I).

${ }^{2} 8$ Stat. I06 $_{5}$ (1934), 47 U.S.C.A. \$ I53(b) (Supp., r95 I).

2 The consequences of not paying rigid attention to the early developments in radio were catastrophic. Siepmann, Radio's Second Chance I-I4 (I946); White, The American Radio II et seq., I 28-30 (I947). Not only was there absent a well-planned method of finance (the first extensive broadcasting was carried on by the set manufacturers as a means of increasing their revenues), but no agency was provided for resolving the technical problems of interference. The first federal regulation of radio, the Radio Act of I9I2, 37 Stat. 302 (IgI2), concerned with radio telegraphy, provided for the licensing of broadcasters by the Secretary of Commerce, but was held insufficient to authorize licensing designed to end interference. Hoover v. Intercity Radio Co., 286 Fed. 1003 (App. D.C., I923); United States v. Zenith Radio Corp., I2 F. 2 d 6r4 (D.C. Ill., I926). The latter decision was followed by the Radio Act of 1927,44

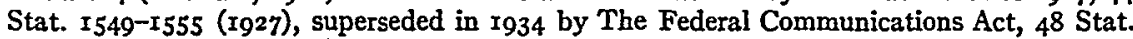
I064 (r934), 47 U.S.C.A. § I5I et seq. (Supp., I95I). 
these first years of large-scale TV will point the course of future development; ${ }^{3}$ the color television case 4 is merely illustrative of their importance. More fundamental, however, are the issues involved in channel allocation and the determination of whether sponsorship is destined to play as leading a role in the formulation of TV programming as it has in radio. These are questions which concern themselves with the ultimate make-up of the programs broadcast. The overwhelming importance of television as a medium of mass communication may well prompt consideration of the nature of such decisions and whether their determination should in the first instance be left in the hands of a regulatory body.

Program variety is conspicuously absent from the American broadcasting scene. ${ }^{5}$ This is not chiefly the fault of the industry ${ }^{6}{ }^{6}$ instances are few where the telecaster is free to program what he wishes. ${ }^{7}$ In very large measure he is a captive of "the product" and the agencies which see it huckstered. ${ }^{8}$ This does not

3 Many have asserted that the possibilities of realigning the make-up of radio broadcasting are pretty much out of question. See, for example, the remarks of Commissioner Denny, Hearings before a Senate Subcommittee on Interstate and Foreign Commerce, Sen. 3333, $_{30 t h}$ Cong. Ist Sess. 38 (I947). As for the dismal state of FM, see ibid., 42-44. See also, Comment, The Impact of the FCC's Chain Broadcasting Rules, 60 Yale L.J. 78, ror (r95I). Paradoxically enough, Siepmann, Radio's Second Chance $1-\mathrm{I}_{4}$ (1946), after devoting an entire book to the tremendous potential of FM as a means of raising the level of programming in its own right, now seems to count chiefly upon the complete devotion of television to mass levels of entertainment, thus deflecting the higher-type programs to radio. Siepmann, Radio, Television, and Society 346 (I950).

4 Radio Corp. of America v. United States, 34I U.S. 4I2 (I95I), upholding the validity of a Commission order which, in effect, requires each set-owner desiring to convert from black and white to color reception to buy an adjusting device. See Comment, "Public Interest" and the Market in Color Television Regulation, I8 Univ. Chi. L. Rev. 802 (1951).

5 According to a survey conducted by Drs. Donald Horton and Dallas W. Smythe, of the Joint Committee on Educational Television, of 33,387 minutes of telecasting over 7 New York TV stations from January $4^{-10}$, 1951 , only $3 \%$ could be classified as informational; $2 \%$ as involving public issues; $x \%$ as religious; and $5 \%$ as music. The remainder was devoted to "light entertainment." Hearings before a Senate Subcommittee on Interstate and Foreign Commerce, Sen. Res. I27, 82d Cong. Ist Sess. 4I-42 (I95I). Similar results have obtained elsewhere.

6 The Federal Communications Commission has itself to some extent recognized this. FCC, Public Service Responsibility of Broadcast Licensees (FCC Bluebook) 40-47 (I946). See further, White, op. cit. supra note 2 , at 54 et seq.

7 Though this has been true of radio for a long time, the effects are accentuated in the case of television, primarily because the latter costs more. Current estimates place the cost ratio at between 4 and 5 to $x$. The high cost of television broadcasting has been one of the principal stumbling blocks to its continued development in Britain. "[T]he television income in I949-50 covered less than one-third of the television expenditure including capital which by BBC practice is being met from revenue." Report of the Broadcasting Committee, I949, Cmd. 81 16, at 93 ( $195 \mathrm{I}$ ). In the United States the cheapest type of network show costs nearly $\$ 300,000$ a season. One frrm spends more than 5 million dollars a year on television advertising. See Mabley, TV Has Traveled A Long Way-But Where's It Going?, Chicago Daily News, section I, p. I, col. I (Nov. I7, I95 I); November Gross, Broadcasting-Telecasting Magazine, p. 6r (Jan. 2I, I952); Siepmann, Radio, Television and Society 327-30 (1950).

${ }^{8}$ As one disgruntled writer remarked, "[r]adio writing, as it has now developed, is simply an adjunct of advertising. The word is fitted to the Product. The Product is God. The word is 
mean, however, that the public on the whole is dissatisfied; surveys indicate the contrary. 9 Yet such tastes are known to be themselves in part a product of previously available entertainment diet, and the fact is undeniable that certain of our minority taste groups are catered to hardly at all.

The sponsorship system necessarily implies submission to sponsorship standards. These standards are geared to sell goods. It is no accident that the Telephone Hour is financed by a monopoly and that the programs of Dupont are selective and high-toned. Neither of these companies need worry about the fickleness of mass tastes. Normally, however, the sponsor-receptor relation is far more direct. Programs are paid for by the purchases which they induce; if practice proves otherwise, the program will be discontinued.

Reception privileges are now effectively tied to the sale of a sponsor's products. Implicit in sponsorship is the power to select what is to be programmed. Much as monopolizing patentees have illegally attempted to condition the use of their monopoly privileges on the sale of non-patentable items, sponsors, through their powers of program selection, have conditioned the character of programs to be broadcast. In so doing, they have foreclosed the listening-market to any whose tastes do not happen to correspond to the level of programs adopted. The only practical difference arises from the fact that the sponsor, in tying up broadcasting time, has no problem of tie-in enforcement; whereas enforcement is the crux of the patentee's whole difficulty. The listener can only take what is offered or leave it. High-level cultural programs have been forced out of the market. ${ }^{\text {o }}$

On the level of broadcasting expenses alone, however, the sponsor's use of his selecting power to tie-in programs is at times warranted. As between a sponsor and a listener who is also a customer the cost of a broadcast is met as part of the product's purchase price. The non-purchasing listener, on the other hand, is the

the interval between the announcements of God... I submit the following ... program.... I. Get back some control over writing, which is now almost exclusively in the hands of the sponsor and advertising agency...." White, op. cit. supra note 2, at 87. For a more analytical view see the FCC Bluebook 40 et seq. (I946).

9 "Listeners, by and large, think well of radio: 80 per cent believe that it is doing either an 'excellent' or a 'good job.' . . . The public, apparently, is not exacting." Siepmann, Radio, Television and Society 84 ( 1950 ). For an exhaustive, if somewhat cynical treatment of the subject, consult Lazarfeld and Stanton, Communications Research I948-1949, 5 I et seq. (r949).

to See, for example, the remarks of Rep. Lane: "Television programs are running wild. They are abusing the hospitality of American homes with lewd images and suggestive language that ... excite those who are under-age and distress every decent adult.

"In the feverish rush to monopolize attention, video has thrown all standards to the winds." 97 Cong. Rec. I,755 (Feb. 28, I95I); Hearings before a Senate Subcommittee of the Committee on Interstate and Foreign Commerce, op. cit. supra note 5, at 27-28.

On the whole, it is probable that television standards have been lower than those of radio. This has certainly been the British experience. Compare the merits of the programs for the 'respective media in the Beveridge Committee Report, op. cit. supra note 7 , at 9 and 83 . Similar results are obtained from a comparison of the lists of radio network programs found in Siepmann, Radio, Television and Society $124-127$ ( $195^{\circ}$ ), with the television surveys cited in note 5 supra. 
recipient of an outright gift. For the non-listening customer, of course, it is too bad the program is broadcast at all, as he pays anyway. Apart from the question of minority tastes, it is apparent from this that our currently low level of programming is the fairest possible. If sponsors, instead of trying to please the majority, had instead chosen Toscanini and Heifetz, the number of persons paying for others' entertainment would be tremendously enlarged.

As far as his listeners are concerned, the sponsor discriminates in very small degree, if at all. The listener is either getting something for nothing, as he refuses to purchase, or if he does purchase, probably pays little more than his fair share of the expense. Nor need the sponsor worry about selecting a program which fails to satisfy the needs of those who neither listen nor purchase. The only group of persons which is being economically imposed upon is that which purchases and whose tastes are disregarded. In this latter instance, of course, the tie-in is again completely unjustified. ${ }^{\mathrm{Ix}}$

The type of discrimination involved here is inherent in sponsorship; a producer has no way of determining who is benefited by his programs and who is not. A rebate scheme would be fantastic and unworkable. But even if the discrimination could be eliminated, no means would have been provided whereby cultural minorities might avail themselves of high-level programs. Such groups are not now in a position to help themselves; nor is it possible for others to go into the business of helping them. The difficulties presented by the wide diffusion of their members, finance, organization and technique render such a course altogether impossible.

Most persons would agree that variety in programming is desirable and that our taste minorities ought at least be given an opportunity to procure higherlevel broadcasts. This comment represents an attempt to outline the various means by which this might conceivably be accomplished.

II

The recent report of the Beveridge Committee on British Broadcasting throws into relief the fact that commercial sponsorship is not the only successful means of financing radio-television media. ${ }^{22}$ The story of British broadcasting is

Ix This does not mean that the sponsor is necessarily "in the wrong" for insisting that the programs he pays for are primarily designed to sell goods. Although it has often been suggested that he does not know what the public really wants and is guilty of excessive commercializing, one cannot really blame him for not risking the stockholder's money on something speculative, when traditional methods seem to have served him so well. If there is to be a change, the initiative should not be expected to come from the sponsor.

s2 Report of the Broadcasting Committee, r949, Cmd. 8116 (r95r). Broadcasting got under way in Britain in r922. The frrst license was issued to the British Broadcasting Company formed by the principal set manufacturers and was later continued on the recommendation of the Skyes Committee of I923. In I926, after inquiry by the Crawford Committee, the name of the company was changed to the British Broadcasting Corporation and its license renewed for another ro years. It was renewed for a similar period in 1936 and again in 1946 for a shorter period. The I946 Charter expired on December 3r, I95I. Ibid., at 6. For the most intensive study of the BBC monopoly development, consult Coase, British Broadcasting: A Study in Monopoly (1950). 
almost entirely the story of BBC, a governmentally controlled monopoly, financed chiefly by the sale of annual licenses to radio and television setowners. ${ }^{{ }^{3}}$ As the sponsorship method of handling programming in the United States was to a large extent fortuitous, ${ }^{14}$ it is interesting to note that the licensing-monopoly approach of Britain was almost equally so. ${ }^{x 5}$ The great disparity in the types of service offered is thus made even more striking.

${ }_{13}$ The early efforts in developing an overall licensing system were not particularly successful. In April of r923 there were 200,000 persons with home made radio receiving sets who had not taken out licenses. Coase, op. cit. supra note I2, at 34 . This problem, once solved, completely cleared the path. Otherwise the system seems to have operated without difficulty. The fee charged to the public for a reception license was tos. Od. until I946 when it was raised to $£_{I}$ for sound and $£_{2}$ for sound and television combined. Report of the Broadcasting Committee, op. cit. supra note 7 , at I22.

${ }^{14}$ American broadcasting history is usually dated from 1920 , when the results of the 1920 presidential election were broadcast over KDKA. Although less than 20 stations were in existence in that year, by the end of I922 nearly 600 were in operation. It was a "free-for-all" without a referee. Various proposals were advanced with a view to meeting the costs of the fast-growing development; among them, municipal financing, reception charges (subscription broadcasting) and philanthropy. None of the schemes envisioned broadcasting as ever anything but insolvent. For example, David Sarnoff, one of the principal spirits of the new industry, looked upon the first major network, NBC, in the following vein: "I feel that... such a company will ultimately be regarded as a public institution of great value in the same sense that a library, for example, is today. Also, it would remove from the public mind the thought that those who are doing broadcasting today (1922) are doing so because of profit to themselves. In other words, it removes the broadcasting company itself from the atmosphere of being a commercial institution." Archer, Big Business and Radio 33 (I939).

Sponsored programs were first tried experimentally over WEAF in I922. The public voice initially rose high in protest, continuing with diminishing force until r929. Since that date, the principle of commercial sponsorship has been all but unanimously subscribed to. See White, The American Radio II-27 (I947); Siepmann, Radio's Second Chance I-I4 (I946).

${ }^{55}$ Although it was certain from the outset that the industry, if it was to develop, would have to do so under the aegis of government due to the scarcity of British frequencies, as late as May, I922, after various parliamentary proposals had been set forth, there was no apparent thought of setting up a broadcasting monopoly. Coase, op. cit. supra note I2, at Ix. The two principal factors which resulted in the acceptance of the monopoly proposal were, first, the desire of the post office to obviate the difficulties involved in selecting those to be allowed permission to broadcast; and, second, the chaotic state of the American broadcasting industry. Ibid., r5-23.

As to finance, various proposals were considered, viz., (I) that the costs be met out of the general public funds; (2) that customs and excise duties be imposed on radio parts; (3) proceeds from license fees paid by retailers and manufacturers; (4) set-owner licenses; and (5) commercial advertising.

As to the last, the Skyes Committee remarked: "We attach great importance to the maintenance of a high standard of broadcast programmes . . . and we think that advertising would lower the standard ... would tend to make the service unpopular, and thus defeat its own ends. In newspaper advertising the small advertiser as well as the big gets his chance, but this would not be the case in broadcasting." Coase, supra, at 35-36. Yet the Committee was not opposed to allowing commercial sponsorship under proper regulation. If the sponsor was willing to be satisfied with mere mention of his name, all right. The present status of commercial broadcasting in Britain is stated in clause 3 of the License and Agreement of 29 th November, r946: "The corporation shall not without the consent in writing of the Postmaster General receive any money or any valuable consideration from any person in respect of the transmission of any broadcast matter by means of stations ... or broadcast any commercial advertisement or sponsored program." "Report of the Broadcasting Committee, op. cit. supra note I2, at 98. The Committee, while recommending the continuation of the provision, was more 
The keynote of $B B C$ programming was early struck by Lord Reith. Criticized for disregarding the desires of the public, he remarked: "It is . . indicated ... that we are apparently setting out to give the public what we think they needand not what they want, but few know what they want, and very few what they need. . . . In any case, it is better to over-estimate the mentality of the public than to under-estimate it." ${ }_{16}$ Although few may know what the British public wants, it is undeniable that the $\mathrm{BBC}$ has decided what they shall have and that the desires of the majority have, to some extent, been disregarded. Whether rightly or wrongly, the corporation early assumed the role of public tutor and has ever since been dedicated to the task of cultural uplifting. ${ }^{17}$ Whether it has succeeded is problematical; the Beveridge Report seems to indicate that it has not. ${ }^{x^{8}} \mathrm{It}$ is certain, however, that the tastes of the minority have been met and perhaps even surpassed. ${ }^{9}$

It seems ironical, from a free enterprise point of view, that the $\mathrm{BBC}$ has traditionally sought to justify its monopoly status primarily on the ground that it is essential to the protection of high broadcasting standards and minority tastes. ${ }^{20}$ Its position before the Beveridge Committee was no different; ${ }_{;}^{2 x}$ and what is more striking, a majority of the Committee was induced to endorse this view..$^{22}$

sharply divided on this point than any other. Ibid., at ro7. Even the majority seemed to be inclined to permit sponsor-intrusion in the case of television, where the British financial problem is severe. Ibid., at I04.

${ }^{16}$ Quoted by Coase, op. cit. supra note 12 , at 47 . The BBC at present maintains 3 main services to its home listeners: (r) Home Service running on weekdays from $6: 30$ A.M. to II : 30 P.3r., consisting of the "broad middle strand of the BBC's broadcasting"; (2) Light Programme, running on weekdays from 9 A.x. to Midnight and devoted to "entertainment in the widest sense" (but not nearly so "wide" as in the United States); and (3) Third Programme, running from 6:00 P.M. to I2 Midnight, representing the acme of culture in British broadcasting.

${ }_{17}$ "The fact is that the majority of those who conceive and direct ... the whole range of the BBC's program services are graduates of Oxford or Cambridge .... and they exemplify both the strength and weaknesses of their alma mater. For today Oxford and Cambridge represent a tradition of education and a concept of culture more nearly suited to the social structure of Great Britain in the late eighteenth century than that of 1950." Siepmann, Radio, Television and Society $\mathrm{I}_{4} \mathrm{O}$ (1950).

${ }^{8}$ The Light Programme has steadily gained in popularity in evening listening, from drawing $44 \%$ of the total audience in the 3 rd quarter of 1945 , to drawing $63 \%$ in the 3 rd quarter of 1949. Home Service listening declined in the same period from 56 to $36 \%$. The entry of the Third Programme in 1946 detracted from Home Service listening, but Third Programme has also lost listeners, falling from $4 \%$ of the total audience in 1946 to less than $\mathrm{I} \%$ in Oct., 1949. Report of the Broadcasting Committee, op. cit. supra note I2, at 57 .

29 For instance, here is a sample of an ordinary evening with Third Programme: contemporary chamber music, Aesthetics of the Gregorian Chant (talk), Character of Charles I (talk), orchestral concert, Medieval Latin poetry, international news talk, interlude and poetry readings. Siepmann, Radio, Television and Society I34 (I950).

${ }^{30}$ Coase, op. cit. supra note $I 2$, at 47 et seq.

3x Report of the Broadcasting Committee, op. cit. supra note 12 , at 72.

22 The majority denied this explicitly, ibid., at 43, while accepting it throughout the Report. See especially, the remarks, ibid., at 170 . Compare the view of Mr. Selwyn Lloyd, author of the Minority Report, ibid., at 2 ro. 
The approach is by way of Gresham's Law, that if competition is permitted, the public will be sought after; and as the public wants entertainment and not culture, programming standards must fall. The proper object of broadcasting is to render a public service, not to compete for listeners or even primarily to please them. ${ }^{23}$ Advertising, and even sponsoring, are proscribed along the same lines. ${ }^{24}$

Despite the fact that BBC standards are geared to a cultural level in excess of that possessed by the public, the average British listener seems quite satisfied.25 The Beveridge Committee, in recommending a renewal of the BBC Charter (largely along the lines of the present one), was doing exactly what was wished..$^{26}$

There are variations on the British and American themes. Canada, ${ }^{27}$ Australia, ${ }^{28}$ and New Zealand ${ }^{29}$ have combined the two in varying admixture. What evidence there is points to the conclusion that a balance somewhere between them is productive of much better results..$^{\circ}$ The fact remains, however, that the principle of governmental regulation of programming has not gained wide acceptance in the United States. Expanding rather than a narrowing of the sphere

${ }_{23}$ "We reject as a guiding principle in broadcasting competition for numbers of listeners." Ibid., at 167. Mr. Lloyd took a somewhat different view: "I fully accept the necessity for one public service system, one of the functions of which would be to cater to minorities. Subject to that proviso, I see no harm in the bulk of other programmes being intended to cater for as large a number of listeners as possible." Ibid., at 207. It is noteworthy that even the most vehement of the objectors to the British broadcasting monopoly, including Mr. Lloyd, did not propose that minority tastes be disregarded and/or advertising be permitted without rigid governmental supervision. Ibid, at $40 \mathrm{et}$ seq. And a survey indicated that most British advertisers are not interested in being able to buy radio time. Ibid., at 217.

24 Ibid., at 72.

${ }^{25}$ According to the Reports of the British Institute of Public Opinion for I946 and 1949, the percentage of the public opposed to the introduction of commercial advertising and in favor of the continuation of the monopoly rose from 44 to $51 \%$. The percentage favoring the introduction of commercial advertising declined from 42 to $33 \%$ over the same period. Ibid., at 105. Compare Coase, op. cit. supra note 12 , at 176.

${ }_{26}$ Ibid.

27 See the Canadian Broadcasting Act, I937, I Edw. VIII 6-24 (Canada, I937). Canadian Broadcasting has been described as a "compromise," a "hybrid." It is run under the auspices of the Canadian Broadcasting Corporation which operates practically as both a regulatory and licensing authority much like the FCC, but differing from it in that it also broadcasts for itself, as in the case of BBC. While sponsoring is permitted, the programming level is rather high and a considerable diversity of choice exists. Sustaining programs occupy over $8 \mathrm{x} \%$ of the total broadcasting time. The principal Canadian difficulty is that of finance. See for a brief discussion, Siepmann, Radio, Television and Society I64-67 (I950).

${ }^{28}$ Australian broadcasting supplies a service somewhat comparable to that of the BBC, but is at a competitive disadvantage as compared with the privately run commercial stations. The latter predominate in a 3 to $\mathrm{I}$ ratio attracting by far the larger number of listeners at any one time. Report of the Broadcasting Committee, op. cit. supra note 12, at I06.

29 New Zealand most nearly approaches the British situation, although some commercial sponsoring is permitted. Tbid. Interestingly enough, the Union of South Africa has also departed from the parent model, introducing commercially-sponsored programs in 1950. Ibid., at ro7.

3o Ibid., at IO4 et seq.; consult further, Siepmann, Radio, Television and Society I10-67 (I950). Compare Lazarfeld and Stanton, op. cit. supra note 9, at $2{ }_{5}$ et seq. 
of private enterprise may yet provide us with an answer. Certainly the British approach is not one to be lightly undertaken. ${ }^{3 \mathrm{x}}$

III

What can be done to provide greater variety in telecasting in the United States? Of the various suggestions which have been put forward, the first may be disposed of briefly. It is a variation on the tried and unsuccessful notion that the Federal Communications Commission will be able to coerce broadcasters into raising the level of programming by threatening to withdraw licenses. ${ }^{32} \mathrm{~A}$ grandiose expression of this policy is the famous Bluebook experiment of 1946,33 foreshadowed in scope only by the Chain Broadcasting Regulations of five years earlier. ${ }^{34}$ Neither of these efforts has been successful. ${ }^{35}$ It is maintained in some

${ }^{3 x}$ While it is outside the scope of this note to consider the political implications of British broadcasting methods, it should perhaps be mentioned that the "power of the Government of the day over the ... [BBC] is absolute. ... The Postmaster General can veto any proposed broadcast ... and in doing so can require the Corporation to refrain from announcing that a veto has been imposed. Any ... Department can require the Corporation to broadcast any announcement ... desired by it." Report of the Broadcasting Committee, op. cit. supra note ${ }_{12}$, at 7 . It is only fair to say, however, that the BBC has in practice been largely independent of government control. Although the first of the above powers has never been formally employed, pressure was exerted in the days before Munich to keep Churchill from speaking on the dangers of appeasement. Coase, op. cit. supra note 12 , at 166 .

${ }^{32}$ Only die-hard elements today challenge the entire basis of FCC program regulation. While the original intent of Congress is perhaps open to question, all doubt has been resolved in favor of the Commission. Johnston Broadcasting Co. v. FCC, I75 F. 2d 35I (App. D.C., I949); Kentucky Broadcasting Corp. v. FCC, I74 F. 2d 38 (App. D.C., I949); Simmons v. FCC, 169 F. 2d 670 (App. D.C., I948), cert. denied 335 U.S. 846 (1948); KFKB Broadcasting Ass'n v. Federal Radio Commission, 47 F. 2d 670, 672 (App. D.C., I93I); Trinity Methodist Church, South v. Federal Radio Commission, 62 F. 2d 850, 853 (App. D.C., I932).

For two of the most eloquent if futile statements of a contrary view, see Segal and Warner, "Frequencies": A Review, Ig Rocky Mt. L. Rev. III (I947); and Miller, Principles of Law Limiting Radio Broadcasting, 9 F.R.D. 217 (I949). See also Note, The FCC, Administrator Extraordinary and Licensor Plenipotentiary, 36 Va. L. Rev. 232 (I950).

33 FCC, Public Service Responsibility of Broadcast Licensees (r946). The publication consists of a statement of policy to be followed by the Commission in passing on proposals for the granting, renewal and revocation of broadcasting licenses. It looks indirectly to the regulation of program content. See Comments, Governmental Regulation of the Program Content of Television Broadcasting, Ig Geo. Wash. L. Rev. $3^{\text {I } 2}$ (I95I); Old Standards in New Context: A Comparative Analysis of FCC Regulation, I8 Univ. Chi. L. Rev. 78 (I950); Government Control of the Content of Radio Programs, 47 Col. L. Rev. I04I (I947); Radio Program Controls: A Network of Inadequacy, 57 Yale L.J. 275 (I947).

34 FCC, Report on Chain Broadcasting (I94I). The rules took the form of a policy declaration that the Commission would not issue a license to any station entering into a proscribed relationship with a broadcasting network. The Commission hoped that by increasing the number of networks and augmenting the independence of the individual broadcasting licensee, the rules would promote a fairer presentation of public issues. Hearings before Committee on Interstate Commerce, Sen. Res. II 3, 77th Cong. Ist Sess. I5I (I94I). Compare the remarks of

${ }^{35}$ Notes 33 and 34 supra. Even where the Commission finds the grossest licensing abuses, it usually renews the offender's license upon receiving an assurance of good conduct in the future. See, e.g., Port Frere Broadcasting Co., 5 Pike \& Fischer Radio Reg. II37 (I949) (almost entire afternoon broadcasting devoted to transmission of horse-racing results); In re Joliet Broadcasting Co.,4 Pike \& Fischer Radio Reg. I225 (I949) (running description of horse races [Footnotes 34 and 35 continued on following page] 
quarters that this is because of the Commission's cumbersome weapons and that if supplied with "cease and desist" powers, results would be different. ${ }^{36}$ To some extent this may be true. But even aside from legislative difficulties, the suggestion seems unrealistic. So long as broadcasting is wholly dependent upon commercial sponsorship, it is difficult to see how the situation can be very considerably improved. ${ }^{37}$ Almost every significant step the Commission has taken in the way of regulating program content has been fought bitterly through the courts..$^{38}$

G. P. Brown, sole owner of the Federal Broadcasting System, Hearings before the House Committee on Interstate and Foreign Commerce, Sen. 658, 82d Cong. Ist Sess. at $4 \mathrm{I}_{4}$ (I95). To date the Commission has neither revoked nor refused to renew a license on the ground that the rules have been violated. Since $194 \mathrm{I}$ it has conducted but one thorough inquiry into network activities and after finding the most flagrant violations of the rules refused to invoke any sanctions. Lee Broadcasting System, 5 Pike \& Fischer Radio Reg. II 79 (1949). The disengagement of the Blue Network from NBC represents their one solid achievement. Radio Corp. of America, Io F.C.C. 212 (1943). Compare Federal Broadcasting System v. American Broadcasting Co., 167 F. 2d 349 (C.A. 2d, 1948), cert. denied 335 U.S. 82 I (r948) (a sad commentary on the present state of network-affiliate relations). See Comment, The Impact of the FCC's Chain Broadcasting Rules, 60 Yale L.J. 78 (1951); White, The American Radio 162 (1947).

[Footnote 35 Con't]

sponsored by racing publication); Metropolitan Broadcasting Co., 5 F.C.C. 5or (r938) (transmission of lottery information); cf. Revocation of License of Panama City Broadcasting Co. (The Florida Cases) 9 F.C.C. 208, 223 (1942); State Capitol Broadcasting Ass'n (The Texas Cases) 8 F.C.C. $445,459,473,479$ (I940); First Baptist Church, 6 F.C.C. 77 I (I939); Joseph C. Callaway, 5 F.C.C. 345 (1938).

Programming considerations have played a much more important part in license application proceedings, but even here the Commission has undertaken only the slightest steps to raise the overall program level. The scope of the cases may be illustrated by the following: Simmons v. FCC, 169 F. 2d 670 (App. D.C., r948), cert. denied 335 U.S. 846 (1948) (proposal to carry network programs exclusively with no regard to local needs); Young People's Ass'n for the Propagation of the Gospel, 6 F.C.C. 178 (r938) (station facilities to be used primarily for religious broadcasting to persons with belief similar to applicant's); Food Terminal Broadcasting Co., 6 F.C.C. 27 I (1938) (broadcasting time to be devoted principally to the dissemination of market information). See also, Johnston Broadcasting Co. v. FCC, I75 F. 2d 35I (App. D.C., I949); Kentucky Broadcasting Corp. v. FCC, 174 F. 2 d 38 (App. D.C., 1949).

${ }^{36}$ See Regents of the University System of Georgia v. Carroll, 338 U.S. 586, 60r (1950); Hearings before a Subcommittee of the Senate Committee on Interstate and Foreign Commerce, Sen. 1333 , 8oth Cong. Ist Sess. I4, 51 (I947). Sen. 658, 82 d Cong. Ist Sess. (I95I), now pending in Committee makes express provision for the issuance of "cease and desist" orders. See generally, Hearings before the House Committee on Interstate and Foreign Commerce, Sen. $658,82 \mathrm{~d}$ Cong. Ist Sess. (I95I).

37 One of the most significant steps ever taken by the Commission to implement real control over broadcasting policies was that contained in the so-called Mayflower doctrine which was thought to preclude licensees from editorializing over their own station facilities. Mayflower Broadcasting Corp., 8 F.C.C. 333,340 (1940). While the basis of the doctrine was only a dictum and it is doubtful whether it was ever intended to say more than that the licensee was expected to be impartial in his overall public approach (see Heffron, Should Radio Be as Free as the Press?, 47 Commonweal 466 [r948] ), the Commission felt it necessary to retract. FCC, Report of the Commission in the Matter of Editorializing by Broadcast Licensees (I949).

${ }^{38}$ See, e.g., Columbia Broadcasting System v. United States, 3 I6 U.S. 407 (rg42); National Broadcasting Co. v. United States, 319 U.S. I9o (x943); Evangelical Lutheran Synod of Missouri, Ohio, and Other States v. FCC, I05 F. 2d 793, 795 (App. D.C., 1939); Trinity Methodist Church, South v. Federal Radio Commission, 62 F. 2d 850 (App. D.C., I932); KFKB Broadcasting Ass'n v. Federal Radio Commission, 47 F. 2d 670 (App. D.C., r93r).

In certain areas, however, the Commission regulates free from judicial interference. This 
The same has been true of other assertions of its power. ${ }^{39}$

Mention should also be made of a bill introduced by Senator Benton which calls for the creation of an eleven-man commission to write an annual report dealing with the content of television programming and to make various suggestions as to how it might be improved..$^{40}$ The report is to be merely advisory..$^{4 x}$ Howls of censorship ${ }^{42}$ have gone up from the industry which, for once, do not seem altogether unjustified. The Supreme Court has never directly passed on the question of whether radio or television is protected under the "press clause" of the First Amendment; but there is a lower court ruling to this effect, ${ }^{43}$ and the Court itself has expressed a similar view. ${ }^{44}$ The doctrine of Mutual Film Corp. v. Ohio Indusirial Commission, 45 that movies are means of entertainment rather than public expression and therefore not entitled to constitutional protection, has long been under attack. ${ }^{46}$ But the analogical jump from movies to television and radio overlooks important differences and would probably not be followed

is due to the fact that a licensee has no standing to appeal in the event his application is granted. 48 Stat. I093, as amended, 47 U.S.C.A. $\$ 402$ (b)(Supp., I95I). See, e.g., Scott, II F.C.C. $37^{2}$ (1946). Sen. 658,82 d Cong. rst Sess. (r95I), while broadening the provisions for review, would seem to leave the Act unchanged in this particular. The Commission's practice of issuing "informal" statements of policy has been termed "regulation by fear." See the remarks of Senator McFarland, Hearings before a Subcommittee of the Committee on Interstate and Foreign Commerce, Sen. Res. 127, 82d Cong. Ist Sess. I7 (195I). It may be doubted, however, whether the actual scope of the practice is as broad as is sometimes supposed. See Comment, Old Standards in New Context: A Comparative Analysis of FCC Regulation, I8 Univ. Chi. L. Rev. 78, 84-86 (1950).

39 See, e.g., FCC v. WOKO, Inc., 329 U.S. 223 (1946); Ashbacker Radio Corp. v. FCC, 326 U.S. 327 (I945); Mansfield Journal Co. v. FCC, 180 F. 2 d 28 (App. D.C., r950); Stahlman v. FCC, I26 F. 2d I24 (App. D.C., I942); Courier Post Pub. Co. v. FCC, I04 F. 2d 213 (App. D.C., 1939).

40 S. I579, 82d Cong. Ist Sess. (195I). A companion bill has been introduced by Rep. Goodwin in the House. H.R. $5^{829}, 82 \mathrm{~d}$ Cong. Ist Sess. (195r). Both proposals, however, pale beside that of Rep. Lane: "I believe ... that the Congress should pass legislation that will set up a censorship board within the ... Commission to scrutinize every telecast in advance. ..."97 Cong. Rec. I 755 (Feb. 28, 195I).

${ }^{41}$ Sen. r $579,82 d$ Cong. rst Sess. (195I).

4 See, for example, Broadcasting-Telecasting, p. 63 (Oct. 29, I95I).

43 Dumont Laboratories v. Carroll, 86 F. Supp. 8r3 (E.D. Pa., I949), aff'd I84 F. 2d 153 (C.A. 3 d, 1950), cert. denied 71 S. Ct. $49 \circ$ (I95I). The point was not mentioned in the Appellate Court opinion, the principal ground of decision in both courts being that the federal government had completely occupied the radio and television fields, leaving no room for state censorship.

4" "We have no doubt that moving pictures, like newspapers and radio, are included in the press whose freedom is guaranteed by the First Amendment." United States v. Paramount Pictures, 334 U.S. I3I, I66 (1948). And see Associated Press v. KVOS, 80 F. 2d 575, 58 I (C.A. 9th, I935).

\section{${ }^{45} 236$ U.S. 230 (1915).}

${ }_{16}^{6}$ See Kadin, Administrative Censorship: A Study of the Mails, Motion Pictures and Radio Broadcasting, I9 B.U.L. Rev. 533, 552 (1939); Film Censorship: An Administrative Analysis, 39 Col. L. Rev. I383, I393 (r939); Censorship of Moving Pictures, I Cornell L.Q. I73, I74 (Igr6). 
in any event. ${ }^{47}$ Other objections to the measure are that the envisaged annual report will disclose no more than is already common knowledge and that the Commission itself has voiced opposition. ${ }^{8}$

A third line of proposals has been represented by educator demand for the allocation of a large number of channels for the use of our educational institutions. ${ }^{49}$ The Commission has responded with alacrity, agreeing to hand over more than two hundred..$^{\circ}$ But the educators are not yet satisfied. Sparked by the action of the New York Board of Regents in demanding eleven frequencies for its own use (where only seven had tentatively been allocated for education throughout the state), the pressure has grown tremendously. The New York proposal envisions an initial appropriation of $3 \frac{1}{2}$ million dollars from the State legislature..$^{\mathrm{sx}}$ Presumably this is also the method to be adopted in Connecticut. ${ }^{52}$

There is certainly nothing wrong with educational control of television channels. Past experience with radio, however, suggests caution. ${ }^{33}$ This commenced with ambitious objectives, but the end result has been largely a succession of failures. ${ }^{34}$ Interest lagged after the newness wore off, and there were pressing problems of finance. The Commission itself became skeptical, and commercial interests were at times given the nod over educational ones. British radio experience on the adult level has been equally disheartening. .5 Iowa State University is the only educational institution actively telecasting today, and this has been made possible, in part at least, through a grant by the Ford Foundation. ${ }^{56}$ The financial problem appears almost insuperable; $;^{57}$ even Iowa State operates on a

47 See Constitutional Law: Possible Impact of Television Rule on Motion Picture Censorship, 39 Calif. L. Rev. 42 I (r95I); Comments on Television and the Law, 25 St. John's L. Rev. 245,263 (I95I).

$4^{8}$ See the discussion in Benton, On Code, Broadcasting-Telecasting, p. 62 (Jan. 21, 1952). As of October, 195I, only Commissioner Coy expressed himself as in favor of the proposal. Tbid.

49 Hearings before a Subcommittee of the Committee on Interstate and Foreign Commerce, Sen. Res. I27, $82 \mathrm{~d}$ Cong. rst Sess. I et seq. (195I).

so Ibid., at I-4.

5 Ibid., at 13 . $\quad 52$ Ibid.

53 For a general discussion, consult Siepmann, Radio, Television and Society 272-79 (r95o); White, The American Radio IoI-III (1946).

54 Tbid.

ss "[B]roadcasting has proved a less forceful instrument of continuous education than was hoped by many... . The main problem ... is not at the sending end but at the receiving end ... that of finding and keeping an audience; the most ambitious attempt in this field ... was abandoned for lack of popular support." Report of the Broadcasting Committee, op. cit. supra note I2, at 2I. The Committee was also skeptical of suggestions for the use of television facilities in the schools. Ibid., $7 \mathbf{I}^{-72}$.

$s^{6}$ Hearings before a Subcommittee of the Committee on Interstate and Foreign Commerce, op. cit. supra note 49 , at 53 .

57 See the remarks of Michael R. Hanna, manager of Cornell University's radio stations, that non-commercial television is simply "unrealistic." Broadcasting-Telecasting, p. 7o (Oct. 22, I951). 
partially commercial basis. It is significant also that the large bulk of the interest has come from secondary rather than collegiate institutions..$^{8}$ On the whole, junior town meetings do not make for much audience interest, whatever their educational value to the participants might be. ${ }^{59}$ The plans of the educators, while to some extent worthwhile, do not seem to hold much promise for any significant alteration of television programming.

Two other possibilities should be noted. The first is the mushrooming theatre-TV development which dates from the Louis-Savold fight. Although theatre-TV as at present conducted does not have any direct relation to current standards of telecasting, its potentialities in this regard are not altogether without substance. It is conceivable that many groups, professional and otherwise, will be willing to pay for the use of closed-channel facilities if and when they become available. ${ }^{60} \mathrm{~A}$ good deal will also depend, of course, on costs. The Federal Civilian Defense Authority has already availed itself of TV-theatre. ${ }^{6 r}$ Nevertheless, the development has met with a violent wave of public protest. A somewhat similar reception has been accorded it in England. ${ }^{62}$ A lawyers' committee (FTPC) has been formed in New York to combat the "menace," and threats have been made to carry the fight into the courts on due process grounds, although the basis for all this is not quite clear. In any event, the group seems to have the sympathy of the broadcasting industry, as well as the public. ${ }^{63}$

Numerous studies have shown the deleterious effects of television on the sports industry. ${ }^{64}$ The profits lost at the gate must somehow be recouped. If other means of remedying the situation are not soon in appearing, ${ }^{65}$ the only

ss Hearings before a Subcommittee of the Committee on Interstate and Foreign Commerce, op. cit. supra note 49 , at 8, I 8 .

so It almost goes without saying that the industry is wholeheartedly opposed to any but the most harmless number of educational channel allocations. For a typical statement, see Why Waste Channels?, Broadcasting-Telecasting, p. 52 (Oct. 22, 195r).

${ }^{60}$ The occasions upon which theatre-TV has been used thus far, however, have resulted in loss of money in almost all instances. Theatre TV, Broadcasting-Telecasting, p. 65 (Jan. 2I, I952).

6x See Civil Defense: Plans More Theatre TV, Broadcasting-Telecasting, p. 80 (Nov. 5, r951).

${ }^{62}$ Report of the Broadcasting Committee, op. cit. supra note I2, at 88 et seq.

${ }^{6}{ }_{3}$ The following are typical: Theatre TV No Knockout: An Editorial, BroadcastingTelecasting, p. 64 (June 25, I951); Movie Fightcast: Stirs Legal Threat, ibid., at 27; AM-TV Blackout, Broadcasting-Telecasting, p. 27 (Sept. 24, 195I); Linking Movies with Television, 54 Commonweal 203-4 (I95I).

${ }^{64}$ The Television Committee of the National Collegiate Athletic Ass'n found that professional baseball dropped some 8 million customers in 1950. Ullman, What About Pay-AsYou-Look TV?, The Saturday Evening Post, p. 30, I33 (August 25, r95I). The National Opinion Research study indicates that somewhat similar results have obtained in collegiate football. See Control "Worked," Broadcasting-Telecasting, P; 59 (Jan. 14, I952). See also TV-Who's Afraid?, 42 Fortune 55 (July, I950); and the various studies cited in Comment, Copyrights and TV: A New Use for the Multiple Performance Theory, I8 Univ. Chi. L. Rev. 757 (195I).

65 See part IV, infra. 
alternative for the promoter may prove to be the closed-circuit. ${ }^{66}$ The same is true for other large-scale forms of entertainment. While it is true that the FCC may have power to preclude the growth of theatre-TV (although it would not if operated on a strict intra-state and leased cable basis), it is also true that neither it nor any other government body is empowered to deprive promoters of their property rights in planned entertainment. With a lone dissent, ${ }^{67}$ the cases are clear that such property exists. ${ }^{68}$ Closed-channel hearings were scheduled to begin on February 25th, I952, having been moved forward from November of last year. ${ }^{69}$

The current efforts of the broadcasting industry at self-regulation, as the second of these possibilities, appear almost completely ineffectual..$^{\circ}$

The final and most promising alternative remains-subscription-TV, the sale of TV programs in the home. ${ }^{7 x}$ Subscription-television has thus far been put to only one substantial test. Zenith Radio Corporation, developers of Phonevision, conducted a 9o-day experiment in Chicago during the first three months of $195 \mathrm{r}$.

${ }^{66}$ The restrictive practices concertedly adopted by various groups of sports promoters and the National Collegiate Athletic Ass'n to cut down TV's inroad into gate receipts are of dubious legality under the Sherman Act, 26 Stat. 209 (1890), as amended, I5 U.S.C.A. \$ I (1948). See Paramount Famous Lasky Corp. v. United States, 282 U.S. 30 (I930); United States v. First National Pictures, Inc., 282 U.S. 44 (I930); Eastern States Retail Lumber Dealers' Ass'n v. United States, 234 U.S. 600 (IgI4). The Justice Department has already filed suit against the National Football League, charging a violation of the Sherman Act in the League's refusal to telecast Philadelphia-played games to the Philadelphian audience. Judge Grim has overruled NFL's motion to dismiss. See the discussion in Football Case, BroadcastingTelecasting, p. 68 (Jan. I4, 1952).

${ }^{67}$ National Exhibition Co. v. Tele-Flash, Inc., 24 F. Supp. 488 (S.D. N.Y., I936).

${ }^{68}$ Twentieth Century Sporting Club v. Transradio Press Service, Inc., I65 N.Y. Misc. 71, 300 N.Y. Supp. 59 (S. Ct., 1937); Pittsburgh Athletic Co. v. KQV Broadcasting Co., 24 F. Supp. 490 (W.D. Pa., 1938). See Comment, Copyrights and TV: A New Use for the Multiple Performance Theory, I8 Univ. Chi. L. Rev. 757, 759 (I95I).

${ }^{69}$ I6 F.R. I93 (Oct. 4, I95I).

${ }^{70}$ Forged in the heat of mounting government pressure, the newly drafted TV Code does not contain much hope for the amelioration of any but the most fiagrant telecasting abuses. Briefly, it provides for a Review Board to enforce the advertising and program rules, suggests certain advertising and program practices along with time limits on advertising, opposes the sale of television time to church and religious groups and contains unwritten but inherent power for the Review Board to check unfair and unscrupulous competition within the industry. Not only is the Code suspectible of a charge of insincerity, but it is somewhat questionable from an antitrust point of view. See American Column \& Lumber Co. v. United States, 257 U.S. 377 (I92I); Paramount Famous Lasky Corp. v. United States, 282 U.S. 30 (1930); United States v. First National Pictures, Inc., 282 U.S. 44 (1930). Broadcasters are already beginning to back out. See Beatty, Rewrite Code?, Broadcasting-Telecasting, p. 80 (Nov. 5, I95I). Benton, On Code, Broadcasting-Telecasting, p. 62 (Jan. 2I, I952). For the full Code text, see Broadcasting-Telecasting, p. 23 et seq. (Oct. 22, 1952).

${ }^{7 x}$ The prospective arrival has already called forth a good deal of comment. See generally, Ullman, op. cit. supra note 64; Benton, Television with a Conscience, Saturday Review of Literature, p. 7 (August 25, I95 $\mathrm{x}$ ). See also, 97 Cong. Rec. 3929 et seq. and articles there reprinted (April I3, I95I); Hearings before a Subcommittee on Interstate and Foreign Commerce, Sen. $127,82 \mathrm{~d}$ Cong. Ist Sess. 24 et seq. (1951). The principle of the development, however, dates back many years. Ibid., at 36 . 
Preliminary analyses of the test indicate that it was successful "far . . . beyond expectation." ${ }^{2}$

Briefly, the image is sent completely over the air, as in the case of any other televised projection; but it is "scrambled" and can be clarified only by means of an impulse sent over a telephone wire after special arrangements with the telephone company. Whenever a set-owner desires to see a program, he merely contacts the phone company, and the charge is recorded on his monthly bill. The total Phonevision box-office for the $9 \circ$-day test period was $\$ 6,75 \circ$, an average of $\$ 22.50$ per family, or \$I.73 per week. ${ }^{73}$

Other systems of subscription-television have been developed, one known as Subscriber-vision, a product of Skiatron Electronics and Television, and the other as Telemeter, controlled by Paramount Pictures. Subscriber-vision does not necessitate the use of telephone wires, and it operates with a punched plastic card, much in the nature of an I.B.M. card, to unscramble the image. It is presently undergoing tests over WOR-TV in New York. ${ }^{74}$ Telemeter relies on a coinslot apparatus attached directly to the receiver and has just completed a series of experimental operations on KTLA-TV in Los Angeles. ${ }^{75}$

Each of the contemplated systems is in a different technical stage of development. Zenith appears to be farthest along, declaring that it can establish Phonevision in any medium sized city within six months after receiving FCC approval. ${ }^{6}$ It seems that each system shares with the other the difficulty of devising a fool-proof means of collection. The method contemplated by Zenith and employed during its Chicago experiment apparently offers the most protection. The pirating problem has also given trouble in the radio field and has thus far been a major obstacle in the successful development of functional music operations. 77 If the telephone company refuses to cooperate with Zenith on Phonevision, this issue may be raised once again in even more acute form.

izenith Radio Corp. Release (May 2I, 195I).

${ }_{33}$ Ibid.

${ }^{74}$ See Meter Methods, Telemeter Tells Plans, Broadcasting-Telecasting, p. 63 (Dec. 3I, I95I).

${ }_{75}$ 'The tests were conducted with short subject films and various test patterns after KTLA's station hours under special authorization from the Commission. It is reported that International Telemeter Corp. will soon apply for permission to conduct a final dress performance on the order of Zenith's Chicago experiment. Tbid. See also, Telemeter Test, Broadcasting-Telecasting, p. 80 (Dec. 3, I95r).

${ }^{6}$ Ullman, op. cit. supra note 64 , at 134 .

${ }_{77}$ Functional music is the counterpart of subscription-TV in the radio industry. Its operations consist in supplying commercial-free FM music to offices, restaurants, and factories. The system operates by means of a supersonic sound device which cuts out all vocal material and is only available to Functional's subscribers. The pirating problem arises from the fact that others have engaged in supplying similar receivers, the owners of which are now in position to hear the commercial-free broadcasts without the costs attendant upon the broadcasting itself. The problem of re-shaping our legal doctrines to take care of the situation is an interesting one. In 1942, the prospect looked so dubious to Muzak Corp. that it refused to go ahead with a similar scheme, even though successful in its tussle with the Commission. Muzak Corp., 9 F.C.C. 287 (1942). See also, Muzak Corp., 8 F.C.C. 58r (194I), noted in I2 Air L. Rev. 299 (194I). 


\section{IV}

The question mark in all this is the FCC. What will it do with the briefs of subscription-TV? The pressures on both sides are certain to be intensive. It is almost too much to expect inaction from the large television networks-NBC, $\mathrm{CBS}, \mathrm{ABC}$, and Dumont-while their television audiences are at least in part taken away. Nor can the moving picture exhibitors and many national advertisers be expected to welcome the new development. On the other hand, millions of dollars have been spent in the creation of the pay-as-you-see techniques; Zenith's Phonevision experiment alone cost more than 600,000 dollars. ${ }^{78}$ The Commission will also find it difficult to overlook the highly favorable results of the experiment.

A decision that would deny the entire principle of the development would seem highly unjustified. Subscription-TV's potentialities as a revenue-supplying device to the individual telecaster seem excellent; regardless of what was broadcast, his ability to combat advertising pressures would be greatly enhanced. With programs being purchased directly, the major problem of providing a means by which taste minority groups might avail themselves of programming facilities could perhaps be met; and, of course, to the extent that a system of direct purchases displaced sponsorship, the discrimination difficulty would be proportionally abated. Indeed, if set-owners chose to allocate their television listening so as to be purchasing directly the large percentage of the time, it is conceivable that sponsorship could be altogether displaced. On the other hand, subscription-TV and sponsorship are not necessarily incompatible; almost every type of program has its appeal for certain kinds of producers. To some extent, producers may find it worthwhile to defray a portion of the setowner's immediate subscription expense. ${ }^{79}$ The effect of subscription-TV on the unpopular theatre-television development, however, is almost certain to be adverse. Promoters of planned entertainment may well find the former a much more profitable means of solving their current attendance problems. ${ }^{80}$ The prospect of outmoded theatre-TV facilities may prove troublesome to the Commission.

It is impossible, of course, to predict with any certainty just what would be broadcast if a system of direct purchase were to be adopted. This would finally depend on demand conditions. On the other hand, it is clear that subscription methods would eliminate pro tanto the necessity for a tie-in of advertising. If our taste minority groups are not interested enough to pay for what they so earnestly insist ought to be given them, familiar analogies suggest that they

${ }^{8}$ Ullman, op. cit. supra note 64 , at 132 .

79 The promoters of Telemeter, however, have announced that they will not permit advertising on any of their broadcasts. Meter Methods, Telemeter Tells Plans, BroadcastingTelecasting, p. 63 (Dec. 3I, 195x).

${ }^{80} \mathrm{It}$ is reported that almost all the officers of NCAA went to Chicago to see an actual demonstration of Zenith's Phonevision. Ullman, op. cit. supra note 64 , at r 33 . 
should cease bemoaning their plight. It is not normally thought unfair that scarce economic goods be allocated on a free market basis.

Since the public appears willing to pay and since channel facilities are still available, it is doubtful whether an unfavorable Commission decision is legally possible. The Supreme Court, in the case of Federal Communications Commission v. Sanders Bros. Radio Station, ${ }^{8 x}$ was emphatic that "[ $\left.t\right]$ he broadcasting field is open to anyone, provided there be an available frequency over which he can broadcast without interference to others, if he shows his competency, the adequacy of his equipment, and the financial ability to make good use of the assigned channel." 82 Although it cannot be denied that the emphasis of the Court has shifted gradually to a recognition of the substantive powers of the Commission under the "public interest, convenience, and necessity" clause, such cases as Columbia Broadcasting System v. United States ${ }^{83}$ and National Broadcasting Co. v. United States ${ }^{8} 4$ should not be considered as repudiating the Sanders Bros. rationale. While affirmatively recognizing the basis of the Commission's broad powers (the scarcity of available frequencies), the Court has never accepted the notion (as have at least two lower federal tribunals), ${ }^{85}$ that broadcasting is something akin to a public utility. This appears most clearly from a comparison of the Columbia and National Broadcasting cases. In the former, the majority assumed that one of the Commission's Chain Broadcasting Regulations, if violated, would constitute automatic grounds for license revocation; while in the latter, when the merits of the regulation were themselves up for consideration, the Court followed the dissent of the Columbia Broadcasting case in its insistence that the validity of each regulation be tested on the basis of individual merit. ${ }^{86}$ (1940).

${ }^{8 x} 309$ U.S. 470 (1940), noted in 26 Wash. U.L.Q. I2I (1940); I3 So. Calif. L. Rev. $45^{\circ}$

${ }^{82} 309$ U.S. 470,475 (I940).

${ }^{83} 316$ U.S. 407 (1942).

$8_{4} 3$ I9 U.S. I90 (1943).

${ }^{85}$ Massachusetts Universalist Convention v. Hildreth and Rodgers, 87 F. Supp. 822 (D.N. Mex., I949); McIntire v. Wm. Penn Broadcasting Co. of Philadelphia, 15I F. 2d 597 (C.A. 3d, r945), cert. denied 327 U.S. 779 (I945). See also Voliva v. WCBD, 3 I3 IIl. App. I 77, 39 N.E. 2d 685 (I942).

Compare Heitmeyer v. FCC, 95 F. 2d 9r (App. D.C., I937). "The people of . . Wyoming, and of its capital . . . are entitled to radio facilities if there be an applicant available and ready to supply them who can satisfy usual and ordinary standards of business safety." Thid., at roo. The Commission itself has in considerable measure recognized this. See, e.g., Voice of Cullman, 6 R.R. I6I (I949) (possibility of diminished revenues to existing licensees held not of itself sufficient basis on which to deny broadcasting license).

${ }^{86}$ While the Supreme Court has done little to define the outward limits of the Commission's discretion, the following cases may serve to indicate them. Verbalized, the action taken may not be "harsh, arbitrary, or capricious." See Ashbacker Radio Corp. v. FCC, 326 U.S. 327 (r945) (where two applications are mutually exclusive, Commission's grant of one without hearings on both held arbitrary); Courier Post Pub. Co. v. FCC, ro4 F. 2d 213 (App. D.C., 1939) (Commission reversed on merits where it appeared that public interest clearly demanded granting of license, applicant being otherwise qualified); Yankee Network v. FCC, ro7 F. $2 \mathrm{~d} 2 \mathrm{I2}$ (App. D.C., I939) (Commission's argument that existing licensee had no rights insofar as standing to contest FCC's license grant to others repudiated, the court making an appeal to the constitution); Heitmeyer v. FCC, 95 F. 2d 9I (App. D.C., 1937) (Commission reversed 
On the technical side, the Commission has been afforded greater leeway; ${ }^{87}$ and, while it is doubtful that a substantive decision on subscription-TV could validly be characterized as "technical," the recent holding in Universal Camera v. $N L R B^{88}$ seems to indicate that, even here, the courts will be much more likely to scrutinize the basis of Commission action than in the past. Nevertheless, in the event of an FCC denial, the future of pay-as-you-see methods would be a matter of grave doubt.

FCC Spring policy announcements ${ }^{89}$ holding that functional or planned music operations contravened the Communications Act of 1934 , if indicative of a permanent Commission view as to the allowability of the subscription principle, raise this question directly. It should be noticed, however, that a comparable proposal was approved as early as $1941 ;^{90}$ and that, in Chicago at least, FM circles seem to feel that the Commission will shortly reverse itself. ${ }^{9 \mathrm{I}}$

In any case, the question remains whether such fundamental broadcasting decisions should be made in the first instance by a regulatory body. It appears obvious that television today is not being put to the best possible use. Legislative action seems called for. ${ }^{92}$ Especially is this true when millions of dollars will

where application was denied on sole ground that applicant intended to form corporation and assign his hoped-for license on certain contingencies). See Comments on Television and the Law, 25 St. John's L. Rev. 245 (I95I); Old Standards in New Context: A Comparative Analysis of FCC Regulation, 18 Univ. Chi. L. Rev. 78 (1950); The FCC: Administrator Extraordinary and Licensor Plenipotentiary, 36 Va. L. Rev. 245 (1950).

${ }^{87}$ See, e.g., Radio Corp. of America v. United States, 34I U.S. 4 I 2 (I95I); Greater Kampeska Radio Corp. v. FCC, ro8 F. 2 d 5 (App. D.C., r939).

${ }^{88} 340$ U.S. 474 (I95I). In the words of Justice Frankfurter, "the trend in litigation is toward a rational inquiry into truth, in which the tribunal considers everything 'logically probative of some matter requiring to be proved." "Ibid., at 497 . See Netterville, The Administrative Procedure Act: A Study in Interpretation, 20 Geo. Wash. L. Rev. I (I95I).

89 "Further Letter to FM Stations Engaged in 'Functional Music' or 'Planned Music' Operations," Public Notice 62825 (April 12, I95I); "Policy Statement Concerning 'Functional Music' Operations," Public Notice F.C.C. 51-445, 62347 (May 4, 195I).

${ }^{\circ}$ Muzak Corp., 8 F.C.C. 58I (I94I).

${ }^{2}$ If not, the Commission will have effectively insulated against an invasion of the Muzak monopoly. Muzak is a corporation engaged in supplying a musical wired service on the order of Functional's FM, but at four or five times the cost. Apart from the question of legality, it would seem that an affirmation of the Spring Policy announcements would bespeak a gross lack of respect for Congressional policy. See the dissenting opinion of Douglas, J., in McLean Trucking Co. v. United States, 32I U.S. 67, 80 (I944). "[T]he Commission may be faced with overlapping and at times inconsistent policies embodied in other legislation enacted . . with different problems in view. When this is true, it cannot, without more, ignore the latter. ... I am of the opinion that the concept of the 'public interest' also involves the anti-trust laws." Ibid., at 80 . Compare Federal Broadcasting System, Inc. v. American Broadcasting Co., I67 F. 2 d 349 (C.A. 2d, I948), cert. denied 335 U.S. 82 I (I948); Mester v. United States, 70 F. Supp. II8 (E.D. N.Y., I947), aff'd per curiam 332 U.S. 749 (I947).

92 The "freeze" on new channel applications, imposed by the Commission in September I 948 because of serious tropospheric interference in some areas, has made Congress' task easier than it otherwise might have been. See FCC, Annual Report 43 (1949). This respite is now about over. See FCC Readying TV Plan, Broadcasting-Telecasting, p. 6I (Jan. 2I, 1952). 
be and, in the case of subscription and theatre-TV, already have been expended in the development and perfection of new transmission techniques. Certainly the present Commission policy of refusing to conduct hearings concerned with "mere paper ideas" should be reconsidered. ${ }^{93}$ Viewed in relation with the history of radio, TV's problems seem to warrant separate legislative treatment.94

\section{THE PEWEE CASE-COMPENSATION FOR SEIZURE OF A GOING BUSINESS}

Though the "national emergency" strike may be a rarer occurrence than one might suppose, ${ }^{x}$ there is little doubt that government seizure of struck or strikethreatened businesses was an extremely useful technique for maintaining uninterrupted production in important industries during World War II and the reconversion period. ${ }^{2}$ But if the technique was useful, it was also ill-defined. Indeed, as one observer has noted, "There is ground for suspecting that the Government consciously avoided any formulation of rules or principles relating to seizure." 3 The Supreme Court, equally reticent for the most part, has done its defining piecemeal. In United States v. United Mine Workers, ${ }^{4}$ for example, the Court refused to define the relationship between the government and the owner of a seized coal mine, and held that as between the government and the employees an employer-employee relationship existed for some purposes but might not exist for others. In United States v. Pewee Coal Co., ${ }^{5}$ a case arising out of the seizure of the nation's coal mines in I943 (but not decided until I95I), the Supreme Court was called upon to define the relationship between the government and the owner of a seized business. Confusion rather than definition was the result. ${ }^{6}$

The specific question confronting the Court in the Pewee case was: Who bears the losses when a business is temporarily seized by the government and continued in operation for profit largely under the management of the owner? The Pewee Coal Company was seized by the government on May I and held until

${ }_{93}$ See Radio Corp. of America v. United States, 34I U.S. 4I2, 420-42I (I95I).

94 Meanwhile, the forthcoming decision of the Supreme Court in the "captive radio" case may contain some meaningful implications. Pollack v. Public Utilities Commission of the District of Columbia, I9I F. 2d 450 (App. D.C., I95I), cert. granted 72 S. Ct. 77, 80 (I951). In the usual arrangement, the transit company enters into a contract with a middleman to install FM receivers in public transportation vehicles at no cost to the utility, both parties securing their income on a concurrent arrangement with the FM broadcasting station. The commuters thus ride to the chant of LSMFT. The Court of Appeals held the operations violative of the Fifth Amendment. Ibid. For an excellent discussion, see Shipley, Some Constitutional Aspects of Transit Radio, Ir F.C. Bar J. 150 (1950).

× Warren, Thirty-Six Years of "National Emergency" Strikes, 5 Indust. \& Lab. Rel. Rev. 3 (I95I).

"Teller, Government Seizure in Labor Disputes, 6o Harv. L. Rev. Ior7 (I947).

3 Ibid., at ro54.

${ }^{5} 34$ I U.S. II4 (I95I).

4330 U.S. 258 (1947).

${ }^{6}$ See Business Week, p. 30 (May 5, I95I). 